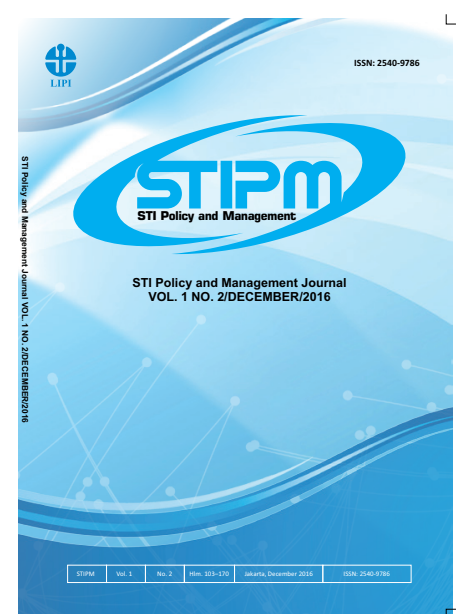

Journal of STI Policy and Management

Publication details, including instructions for authors and subscription information: http://www.stipmjournal.org/

\title{
Institutional Transformation of Local Innovation Systems in Farmer Community of Belu, East Nusa Tenggara
}

Febtri Wijayanti, Savitri Dyah, Rachmini Saparita, and Akmadi Abbas

R\&D at Center of Appropriate Technology Development Indonesian Institute of Sciences, Indonesia

Version of record first published: 15 December 2016

To cite this article: Wijayanti, F., Dyah, S., Saparita, R., and Abbas, A. (2016). Institutional Transformation of Local Innovation Systems in Farmer Community of Belu, East Nusa Tenggara. Journal of STI Policy and Management, 1(2), 137-151

To link to this article: http://dx.doi.org/10.14203/STIPM.2016.51

ISSN 2540-9786 (Print); ISSN 2502-5996 (online)

Accreditation Number: 622/AU3/P2MI-LIPI/03/2015

Full terms and conditions of use: https://creativecommons.org/licenses/by-nc-sa/4.0/

You are free to:

- Share : copy and redistribute the material in any medium or format

- Adapt : remix, transform, and build upon the material

- The licensor cannot revoke these freedoms as long as you follow the license terms.

Under the following terms:

Attribution - You must give appropriate credit, provide a link to the license, and indicate if changes were made. You may do so in any reasonable manner, but not in any way that suggests the licensor endorses you or your use.

NonCommercial - You may not use the material for commercial purposes.

ShareAlike - If you remix, transform, or build upon the material, you must distribute your contributions under the same license as the original.

No additional restrictions - You may not apply legal terms or technological measures that legally restrict others from doing anything the license permits.

Notices:

- You do not have to comply with the license for elements of the material in the public domain or where your use is permitted by an applicable exception or limitation.

- No warranties are given. The license may not give you all of the permissions necessary for your intended use. For example, other rights such as publicity, privacy, or moral rights may limit how you use the material.

- If you copy the dataset merely to extract the uncopyrightable data elements would not need permission to do so. However, if you republish the full dataset or using the copyrightable data layers require a permission from PAPPIPTEK-LIPI. 


\title{
SCIENCE, TECHNOLOGY AND INNOVATION POLICY AND MANAGEMENT (STIPM) JOURNAL Volume 01, Number 02, December 2016
}

\author{
FOREWORD by EDITOR-in-CHIEF
}

We are very pleased to present the second issue of the Science, Technology and Innovation Policy and Management (STIPM) Journal. We are very excited that the journal has attracted papers from many countries. The variety of paper submissions has supported the international-level initiatives of the journal. Since the beginning of the year, a number of articles have been sent to us. Six articles are published in this issue, while others are still under the first or second phase of review and will follow in the subsequent issue.

In this issue, we present six articles on issues of technology and innovation development and policy at national-, regional-, and firm-level, written by scholars from Australia, Japan and Indonesia. The first article investigates the technological capability of the milk processing industry in Indonesia. The second article investigates mass production of innovation in the business model of start-up companies. The third article explores the diverse effects of four types of mobility on university entrepreneurship. The fourth article explores institutional transformations in local innovation systems used by the farmer community of Belu, East Nusa Tenggara, Indonesia. The fifth article analyzes the transition of bioplastic development in Indonesia, and the last article investigates the effectiveness of subsidies in technology adoption using the case study of reverse osmosis membrane technology in Mandangin Island, East Java, Indonesia. All articles have gone through editorial review by prominent experts.

I would like to thank the authors who have submitted articles to STIPM Journal for their trust, patience and timely revisions as well as for trusting Editor and Editorial Board. I encourage authors to submit their manuscripts. This scientific work is published widely on an open access policy.

My gratitude also goes to all members of the Editorial Board and reviewers who have contributed to this second issue, all of whom increase the quality of articles in this journal even more. We continue to welcome article submissions in the field of science, technology and innovation policy and management.

We wish you a 2017 Happy New Year!

Jakarta, December 2016

Editor-in-Chief 


\section{JOURNAL OF STI POLICY AND MANAGEMENT}

Volume 1, Number 2, December 2016

\section{LIST OF CONTENTS}

How Does the Milk Processing Industry in Indonesia Develop Their Technological Capability?

Budi Triyono, Chichi Shintia Laksani, Muhammad Zulhamdani, and Saut Siahaan $103-116$

Mass producing innovation: a case investigation on why accelerators might not be a paradox

Andrew Barnes

Exploring Diverse Effects of Four Types of Mobility on University Entrepreneurship

SatokoYasuda

Institutional Transformation of Local Innovation Systems in Farmer Community of Belu, East Nusa Tenggara

Febtri Wijayanti, Savitri Dyah, Rachmini Saparita, and Akmadi Abbas

Dynamics of Bioplastics Development in Indonesia

Qinan Maulana B. Soesanto, Dian Prihadyanti, Hartiningsih, and Trina Fizzanty.

Effectiveness of Subsidies in Technology Adoption: A Case Study Involving Reverse Osmosis (RO) Membrane Technology

Nur Laili, Rendi Febrianda, and Iin Surminah 163-170 



\title{
Institutional Transformation of Local Innovation Systems in Farmer Community of Belu, East Nusa Tenggara
}

\author{
Febtri Wijayanti a, Savitri Dyah a, Rachmini Saparita ${ }^{\text {a }, \text { Akmadi Abbas }}{ }^{a}$ \\ Development Center for Appropriate Technology, Indonesian Institute of Sciences
}

\begin{tabular}{|c|c|}
\hline ARTICLE INFO & ABSTRACT \\
\hline $\begin{array}{l}\text { Article History: } \\
\text { Received : } 27 \text { January } 2016 \\
\text { Revised : } 27 \text { November } 2016 \\
\text { Accepted : } 2 \text { December } 2016 \\
\text { Available online : } 15 \text { December } 2016 \\
\text { Keywords: } \\
\text { Institution } \\
\text { Local innovation system } \\
\text { SIDa-Belu } \\
\text { Transformation }\end{array}$ & $\begin{array}{l}\text { Innovation is an important factor for economic development, } \\
\text { especially for a developing country. Lack of access to innovation } \\
\text { and information has contributed to its low agricultural productivity. } \\
\text { In Belu, East Nusa Tenggara, a similar situation is taking place. } \\
\text { Government initiative SIDa-Belu has tried to bring innovation } \\
\text { closer to community, particularly to farmers in Belu. Institutions are } \\
\text { one factor that must be considered in the process of innovation. The } \\
\text { study focuses on the process of institutional changes among actors in } \\
\text { local innovation systems; in this case, the SIDa-Belu. The objective } \\
\text { of the study was to analyze the institutional transformations that } \\
\text { occurred in the implementation of the SIDa-Belu concept. The } \\
\text { attitude of actors in the SIDa-Belu was considered as an indicator } \\
\text { in evaluating the SIDa-Belu concept. Primary and secondary data } \\
\text { were collected using questionnaires, guided interviews and focus } \\
\text { group discussions (FGD). The questionnaires were used to map } \\
\text { the performance of each variable. In-depth interviews and FGD } \\
\text { were used to obtain qualitative data. A descriptive method, namely } \\
\text { the Structure, Conduct, Performance (SCP) analytical approach, } \\
\text { was applied to measure the institutional performance of SIDa- } \\
\text { Belu models that have been implemented in the subdistrict of } \\
\text { West Tasifeto, Belu. The analysis was conducted by comparing } \\
\text { conditions before and following the SIDa-Belu implementation. } \\
\text { Institutional change is a process of transformation that is part of } \\
\text { development. The agreed rules and controlled behavior in each } \\
\text { actor and among actors of SIDa-Belu produce a well-performing } \\
\text { local innovation system. The institutional transformation occurred } \\
\text { from minor rules, unfocused and short-term goals, into active } \\
\text { farmers' groups having mutually agreed rules, with long-term } \\
\text { goals. Successful institutional transformations were seen in the } \\
\text { changing attitudes in each of the actors within the SIDa-Belu } \\
\text { Model towards a better organization, benefiting farmers as the } \\
\text { object of the program. }\end{array}$ \\
\hline
\end{tabular}

\footnotetext{
* Corresponding Author.

E-mail: febtriwijayanti@yahoo.com
} 


\section{INTRODUCTION}

It is generally agreed that innovation can play important role in economic development, as shown by many developed countries. In Indonesia, this is also shown by agriculture sector growth in 1970s through the green revolution program. In this era, new agriculture technologies increased agriculture production and productivity. The technologies were, among others, new and advanced rice variety seeds, irrigation and fertilizers. Postharvest technology was introduced, disseminated and adopted by farmers, and in turn Indonesia achieved rice self-sufficiency. Therefore, innovative activity is a fundamental key for economic development and entrepreneurship, as stated by Audretsch and Link, (2012). Innovative activity is the key to the economy, and entrepreneurship is a fundamental behavior upon which innovation is based. According to Schumpeter, priority should be given to the role of innovation in not only transforming economic systems to new levels of performance, but also in spreading prosperity (Juma, 2014). East Nusa Tenggara remains the province with the fifth lowest Gross Domestic Income (GDI) and the lowest Human Development Index (HDI) in Indonesia. Lack of access to innovation and information has contributed to its low agricultural productivity. The local government has been trying to bring technology closer to farmers through an initiative called SIDa, which stands for Sistem Inovasi Daerah (Local Innovation System). Some agricultural technologies were delivered and transferred to farmers.

In the case of Belu, the condition is due to lack of access to innovation and innovation information and is worsened by infrastructure inadequate for supporting economic activities. Technology can be one of the solutions to cope with the condition. However, although the government has promoted the technologies to support agriculture development in the area, farmers' economic situations have not been improved, especially for poor farmers. This condition occurred because many of the government's programs to help poor farmers have not been well-distributed (Dyah, Saparita, Abbas, Mulyadi, \& Hidayat, 2011). Hence, many of the technologies disseminated by the govern- ment through several programs are not utilized or adopted by the farmers.

The low adoption of the promoted technologies in Belu is due to unsuitable and unevenly distributed technologies in each location, not to mention that institutions are not taken into account during the dissemination process. In fact, institutions are an important factor in sustainable capacity building, as it plays a role in managing the technology or innovation's ability to increase farmers' capacity. Managing here means activities related to disseminating, maintaining, and providing innovation or information on innovation needed by the farmers in order to increase their production and productivity, increase their income and, in turn, alleviate their poverty.

Every community or area is actually equipped with such an institution but are mostly not optimizing it, let alone for managing innovation. Considering that innovation is important for local capacity building and that access should be available to farmers, a local institution is needed to play an intermediary role for farmers to obtain access to innovation. Therefore, to empower poor farmers and alleviate poverty, the local government supports the Local Innovation Systems initiative called SIDa-Belu. SIDa-Belu is developed together by $R \& D$ institutes within LIPI, district-and subdistrict-level local governments, farmers' groups and farmers, and then is implemented at the subdstrict and village levels (Saparita, Dyah, Mulyadi, Hidajat, 2012).

Referring to Jacobsson and Johnson's (2001) statement that "the aim of innovation systems is to improve social function", SIDa-Belu is developed in order to assist the government in alleviating poverty in the area by helping farmers, especially poor farmers, obtain access to innovation and information. In this case, SIDa-Belu is built as the intermediary institution to bring innovations or needed technologies closer to the community.

SIDa-Belu is built by optimizing local institutions which function as extensions for farmers, namely extension offices. However, this would only work in one direction, i.e. extension workers give information to farmers or assist farmers whenever there is any government programs allocated in the area. The relationship only involves 
disseminating, with no active interaction and no feedback from farmer to government or $R \& D$ institutions. Almost all of the programs or disseminated technologies are top-down programs, resulting in the disseminated technologies being underutilized. In addition, the technologies are unsuitable to local conditions, too expensive, too complicated, or too difficult to apply. Therefore SIDa-Belu is built by equipping local institutions with needed facilities so that they are able to play their role properly as intermediary institutions where farmers can easily gain access to innovation they need.

SIDa-Belu is built in reference to the joint regulations of Ministry of R\&D and Technology (MRT) and Ministry of Home Affairs (MOHA) No. 03/2012 and No. 36/2012 on Strengthening Regional Innovation Systems. The existence of local innovation systems in an area is expected to overcome the gap between science and technology (S\&T) and community, especially in remote areas (off Java Island, where the central economic growth lies). However, many obstacles often occur during implementation. A network that has been built as a model system would often not run smoothly during the application in a certain area. One of the factors causing the problem is the element of overlooked institutions, which are not managed properly.

Besides the extension offices, there are many local institutions in the area, i.e. farmers' groups, cultural/customary organizations (lembaga adat), farmers' unions, etc. However, in this case the extension offices are more suitable to play the role of the intermediary institution and manage local innovation systems as they require the minimal facilities needed for managing innovation systems, as opposed to the others. Institutions should not be confused with institutes. An institute refers to an organization or formal body built with a clear legal basis, while institutions are the norms and rules applied and agreed upon by the community. Basically, institutions are the result of interactions between its constituent components, namely the individual/person, similar interests, rules, and structures (Horton \& Mackay, 2003).

The institution as an element of the local innovation systems has a function in controlling or managing interactions that should happen within the elements of innovation systems and among actors of innovation. However, making the SIDa-Belu Model an active institution is required. The transformation or institutional change is in accordance to the local needs and condition. Done correctly, it would bring about a new institution more suitable to community members, namely farmers as the end users of the technologies. In Belu's case, the transformation occurrs as individual farmers became farmers' groups, and subsistence farmers became marketoriented farmers.

The study focuses on understanding the process of institutional change among actors in the local innovation systems of SIDa-Belu. The objective of the study is to analyze the institutional transformation or changes that occurred during the implementation of SIDa-Belu. The actors' attitude changes in the SIDa-Belu are an indicator in evaluating whether or not the SIDaBelu concept is functioning.

There are three elements of institution will be analyzed, namely: (i) the intermediaries sector (disseminator/diffusion actors); (ii) innovation users (farmer/community); and (iii) innovation providers (Center for R\&D). These three elements represent innovation actors. Innovation disseminators are the intermediary institutions managing the link between innovators and users. In this case, the disseminator is the Local Extension Office (LEO) that manages SIDa-Belu at the subdistrict level and the Agency for Extension and Food Security Board (AEFSB) at the district level. The innovation users are the farmers in West Tasifeto subdistrict of Belu district. The innovation providers are $R \& D$ centers or grassroots innovators.

Primary and secondary data were collected using questionnaires, guided interviews and focus group discussions (FGD). The number of respondent are 30, divided over three villages of Taliren, Fatukrin, and Aimalay. Questionnaires used to map performance for each variable. In-depth interviews and FGDs were used to obtain qualitative data. A descriptive method, SCP (Structure, Conduct and Performance), was used as an analytical approach to measure the 
institutional performance of SIDa-Belu models that have been implemented in West Tasifeto sub-district. The analysis was conducted by comparing the conditions before and after SIDa-Belu were implemented.

Data collection was conducted in May 2011 through survey using questionnaires. The survey was conducted in coordination with local researchers and staffs of local Agricultural Office. To get comprehensive information, several Focus Group Discussions (FGD) were conducted in April-May 2012 in different level, i.e. FGD with farmers representing the users of innovation, FGD with staffs in sub-district level and extension workers representing the disseminators and intermediary institutions, FGD with staffs in district level representing the policy makers. In May 2012, several dialogues also conducted based on survey results and FGD. Results of the dialogue was that local innovation systems model (SIDa-Belu) should be developed in accordance to the local needs. In 2013, several dialogues also conducted before implementing the SIDa-Belu Model to assure it was accepted by the people where the model was implemented (Bakustulama Village). In April 2015, in depth interviewed and FGD were also conducted by authors to evaluate how SIDa-Belu model was adopted, adapted and functioned by the people.

The SCP method is derived from the neoclassical market analysis to identify a correlation between the structure of an industry and its performance (Edwards, Allen, \& Shaiik, 2006). However, this method can also be applied to measure the institutional performance of local innovation systems, as the market is also an institutional system.

Structure in the SCP method refers to relationship patterns among phenomena. The elements are: (i) encourage the emergence of institution, (ii) legal basis of the institution, and (iii) position of each actors within the organizational structure. The aspect of 'conduct' in the SCP method shows the actors' behavior toward innovation in an institution. Performance' in the SCP method shows the form of work in activities agreed to be carried out within institution.
An innovation system is described by Freeman (Audretsch, \& Link, 2012; Muller, 2009), as a network of institutions that interact in providing, modifying and diffusing technology. From this definition, Lundfall (2007) adds a social element as a binder in occurring interactions, showing that in different regions, systems might be different. Meanwhile, the Organisation for Economic Cooperation and Development (OECD) perceives innovation systems as a set of market and nonmarket institutions in a country which affects the direction and speed of innovation and technology development (OECD, 1999).

In alleviating poverty, Carayannis \& Grigoroudis (2014) consider innovation as the key in increasing competitiveness and productivity. Increases in farmers' productivity, it is believed, can reduce poverty (Carayannis \& Grigoroudis, 2014).

In several definitions of innovation systems, institutions are an important element in managing the occurring interactions between actors in an innovation system and within existing elements. The functions of institutions in innovation systems were described by Johnson (2001) as follows: (i) reduction of uncertainties; (ii) resolution of conflicts; (iii) provision of incentives for learning and participation in innovation processes; and (iv) effective and efficient management of resources.

\section{THE IMPLEMENTATION OF THE SIDA-BELU MODEL IN WEST TASIFETO SUBDISTRICT}

Innovation processes require the consideration of numerous factors, both internal, which concern the multiplicity of agents involved and interaction mechanisms, and external, which are the set of policies and competitiveness factors determining the environment in which the companies operate (Arranz, de Arrobaye \& Fdez, 2009). As already described, in Belu, one of the causes of poverty was the low usage of technology. Here, SIDa-Belu has tried to bridge innovation from $\mathrm{R} \& \mathrm{D}$ institutions as the technology provider to community/business. However, interactions among actors were needed to make the systems run and benefit the actors, particularly actors in the community. 
A study regarding innovation and technology utilization in 2011 illustrated that the use of technology/innovation in Belu was categorized as low. The low innovation utilization had rendered the people unable to use/cultivate the full amount of land they held. In addition, they were also not able to cultivate the land for the full extent of the year. As a result, production was limited and they could only meet their own consumption needs - or even less. It also affected their income, which was low, and therefore they remained in poverty. Due to a low income, they cannot save money for technology or technology application, and therefore the land utilization was not optimal (Dyah, et al., 2011).

The innovation systems that could give poor farmers access to technology was then built. However, to build the model, it needed greater and more active interactions between the universities, $R \& D$ centers, companies and government, and was regarded as a necessity to fulfill the requirements of services, $R \& D$ and development (Arranz et al., 2009). Hence, the SIDa-Belu Model in West Tasifeto subdistrict was built by involving academics as innovation providers, local government as the area owner, extension workers as innovation disseminators, and farmers as innovation end users. The model was built by taking FGD results and intense dialogue conducted with the local government, farmers and farmers' groups into account. The SIDa-Belu Model was developed by considering the nine elements of the innovation systems identified during the process of problems identification in existing local innovation systems. Those elements are: innovation disseminators (LEO), innovation users (farmers), innovation and information flow, management of innovation, innovation system institutions, infrastructure, environmental support (social and local politics), innovators and the availability of information and innovation (Saparita, Dyah, Abbas, Hidajat, 2013).

Lakitan (2010) states that innovation systems in the agriculture sector should be based on local potency and the conditions of each area. The right strategy in developing technology would build the nation's independence and maximize the added value of products and services generated from local resources. Based on Belu's conditions, adapting from Arnold and Bell (2001) in World Bank (2006), this paper has developed its concept of agricultural innovation systems as shown in Figure 1.

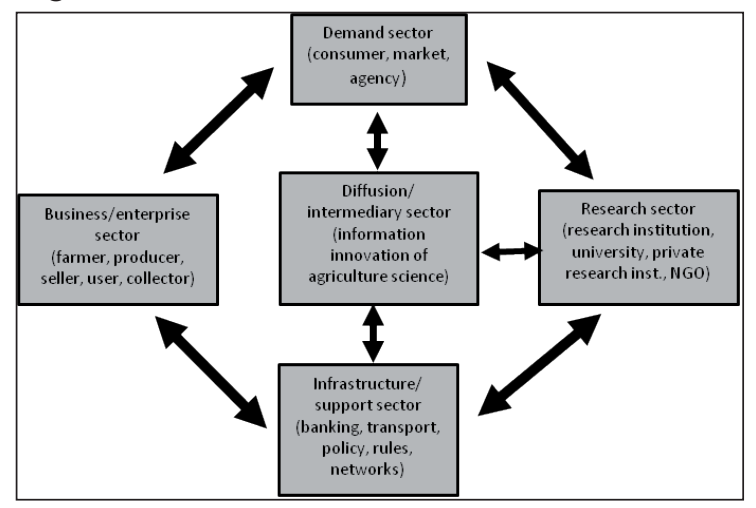

Figure 1. Science and technology innovation systems in agricultural sector

In Figure 1, innovation systems of S\&T in agriculture have at least five institutional elements. Each of these institutional elements should be able to synergize in the process of diffusion and adoption of technology. Figure 1 shows the essential components in the system of innovation and systems flow, and also shows the learning process described by the alternating direction of the arrow. Figure 1 also shows the importance of the role of intermediary institutions in bringing innovations closer to farmers for their benefit.

Dissemination and utilization of technology/ innovation are leverages in overcoming poverty. The role of S\&T innovation in taking on poverty is recognized by the government and supported by a series of regulations and legislation. Among others are: President of the Republic of Indonesia Instruction No. $03 / 2001$ on the Implementation and Development of Appropriate Technology, Act No. 18/2002 on National System of R\&D, Development and Application of ST, and Government Regulation No. 03/2005 on Technology Transfer, Intellectual Property Rights and Results of R\&D and Development Activity; these demonstrate that technology is important for national development and growth.

An effective innovation system will increase the utilization of innovation, which will lead to a better welfare. In the case of SIDa-Belu, interac- 
tions between government as the intermediaries sector, R\&D center and community need supporting policy, specifically local regulation, as guidance in applying the SIDa-Belu system. The concept of an effective innovation system is characterized by interactions occurring within the elements of the system, in accordance to each role. In turn, good process interactions are characterized by its productivity and generate profit or mutual benefit in various forms for the parties that interact. Linkages and the networking value chain are the basis for strengthening the innovation system and need to be developed further. Linkages and networking in S\&T innovation systems concerns not only business activities, but also non-business activities.

The SIDa-Belu was built by involving all related parties and implemented with West Tasifeto subdistrict as the location of the intermediary institution and Bakustulama Village as the user (farmers/community). At the beginning, implementation at the village level involved farmers from two hamlets, i.e. Fatukrin and Taliren. These two hamlets were actually new settlements in the area for refugees from Timor-Leste. During the implementation, another hamlet joined the implementation program: Aik Malaik, which was a hamlet of native inhabitants. These two hamlets possessed different conditions. While the third hamlet had enough agricultural land on average, farmers from the first two hamlets had no access to agricultural land, so that they had no income source. They only planted corn in their home yard as a staple food for their own consumption.

On the other hand, the third hamlet had enough land, with an average size of one hectare per household. However, they were only able to cultivate half of the land due to extremely or very dry climate that required appropriate technology application to solve; hence, their production was also mostly for their own consumption. Their involvement in the SIDa-Belu implementation had changed their productive activities, which now benefited them. Through the SIDa-Belu, the extension workers managed to give farmers from Fatukrin and Taliren access to land and increased the production for farmers from Aik Malaik.
Here, SIDa-Belu played the role of intermediary and opened access for farmers according to their needs. To farmers from Fatukrin and Taliren, land for production were very crucial; through the SIDa-Belu network, the extension worker managed to negotiate with the local landlord to lend the uncultivated/unused land to these farmers. Therefore, during the implementation in 2013-2014, farmers from those two hamlets managed to cultivate vegetable crops three times a year, with assistance of extension workers in the form of seeds to be planted. Vegetables were chosen because they require a short time in cultivation and have relatively high economic value. Meanwhile, farmers from the third hamlet benefited from information on better vegetable cultivation. Before they were involved in the SIDa-Belu program, they planted vegetables by scattering the seeds, but changed their method after they received information from the extension workers on how they could increase their production by applying distance between plants. By applying the technique, the farmers could yield $29 \%$ more produce than simply spread planting. With the benefit they received, the farmers were confident to be involved in SIDa-Belu and agreed to maintain and change it if needed to better suit their needs.

\section{INSTITUTIONAL TRANSFORMATION OF SIDA-BELU MODEL}

\section{A. Structure of the SIDa-Belu Model}

The implementation of SIDa-Belu Model refers to the joint rules of MRT No. 03/2012 and MOHA No. 36/012 on Strengthening Regional Innovation Systems. The parameters of institutional structure of SIDa-Belu model are: (i) what encourages the emergence of institutions; (ii) what legal basis the institution operates on; and (iii) the position of each actor in the structure of organization.

Innovation and diffusion are a systemic, dynamic and non-linear process in which technological and institutional factors interact in a context of inherent uncertainties. The dynamics of technological and institutional change unfold at many different levels, and on different time scales. Innovation is non-linear, as systems typi- 
cally show with increasing returns from adoption, so that small changes in initial conditions can result in radically different outcomes. Innovation processes are uncertain because neither future technological and market opportunity nor policy and regulatory regimes can be accurately predicted (Foxon \& Pearson, 2008). The model of SIDa-Belu was built and implemented to address uncertainty resulting from the dynamic process of the diffusion of innovation.

The institution of SIDa-Belu Model was needed to rekindle farmers' interests in obtaining information and technology. For some time, information and technological assistance from the government often created conflict in the community for several reasons; for instance, the technology was inappropriate and distributed unevenly. The technology was inappropriate because the technology or information provided by the government did not fit their needs. The uneven distribution caused conflict among farm- ers' groups and led to low trust in the government. It was believed that those who were close to the government officers must receive the government assistance consistently. There were also cases of fictitious farmers' groups, namely groups that were formed only for getting government aid, and going inactive after receiving the aid.

In consideration of the location where SIDaBelu model was implemented, people thought that it needed to change for better results. In the SIDa-Belu Model, a network was the most important part of the system because it connected actors involved in the system. Figure 2 shows the structure of the network of actors in the system before the implementation of SIDa-Belu Model.

Figure 2 illustrates that farmers' groups became the object of a program organized by the government or innovation providers. A structural weakness of this network is the lack of communication between actors in the system upon implementation. The farmers groups' position

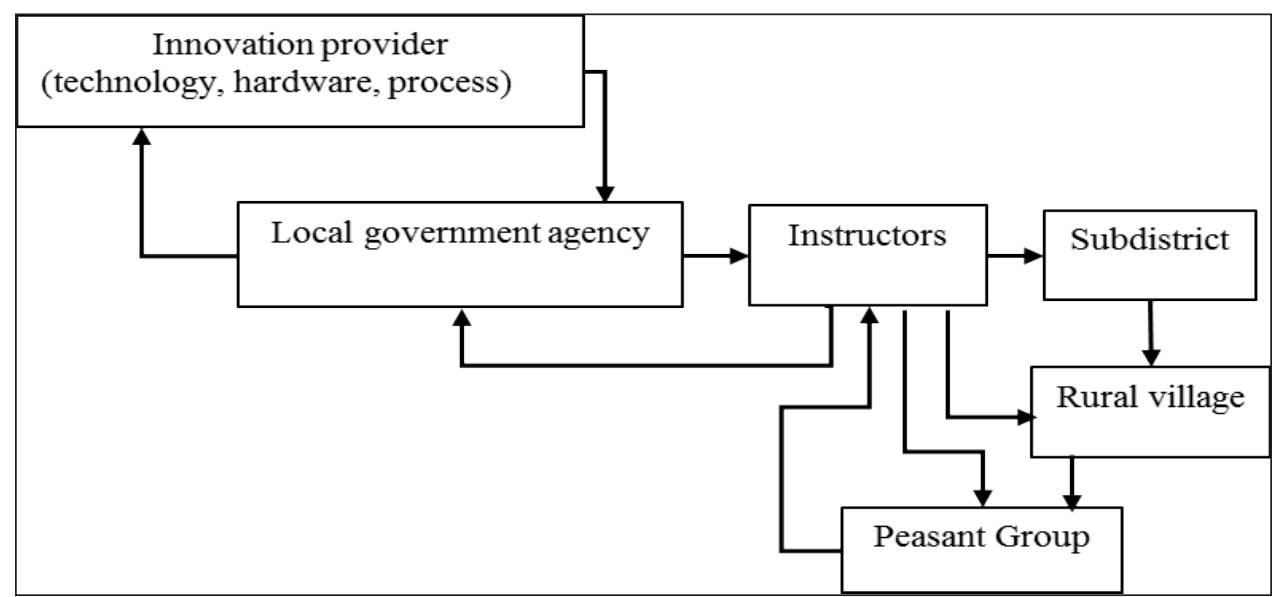

Figure 2. Network Structure of Innovation Actor before SIDA-Belu being Implemented

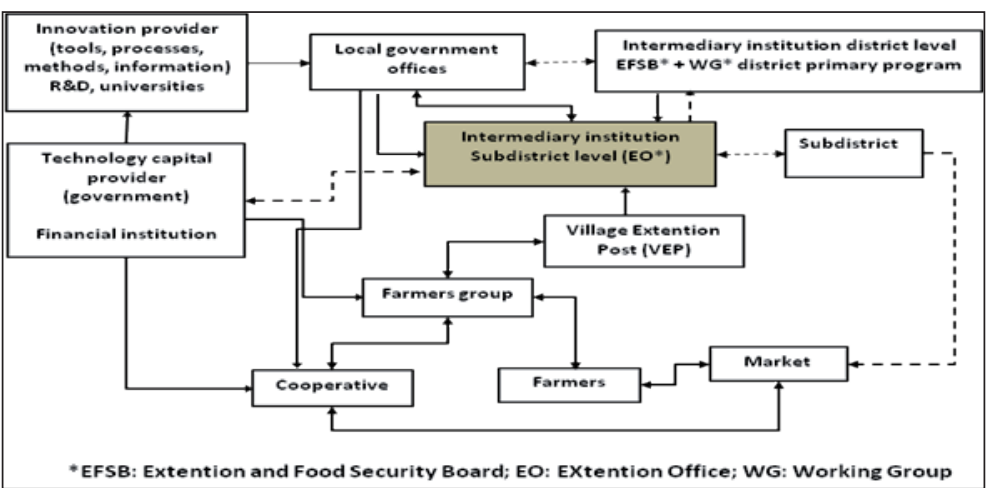

Figure 3. Networking Structure of Innovation Actors 
here are as the object of innovation recipient, passive, individually dependent to extension workers. Therefore, the opportunity for unequal distribution of government aid, and subsequently the number of fraudulent groups, soared.

After the implementation of SIDa-Belu Model, the networking of actors improved as shown in Figure 3 (Saparita et al., 2013). This system was derived from several focus group discussions involving many actors, namely between local government officers and intermediary institutions, farmers and farmers' groups, and intermediary institution and farmers. The discussion generated decisions which they agreed upon, such as the integration of SIDa-Belu into the management of the LEO, where farmers and farmers' groups usually got assistance. When the government developed a program for farmers, the LEO could lead the groups in need. By applying this system, the government programs for farmers were expected to be distributed fairly and evenly.

\section{B. Conduct of Actors in SIDa-Belu Model}

The mainstream view on innovation shifts from innovation as a mere technical device towards a whole process on active innovation (Rijn, Bulte \& Adekunle, 2012). The institutions cannot be transferred like technologies. The institutional transformation is full of political traps because it directly affects the distribution of values among stakeholders (Hounkonnou et al., 2012). Innovation needs a system to be successfully transferred to a community or business.

The local government (Belu District) committed to a SIDa-Belu Model implementation by involving the Working Group for District Primary Product Program (WGDP3) as well as the District Monitoring and Evaluation Group (Saparita et al., 2013). During the SIDa-Belu implementation, the important role of intermediary institutions was highlighted; in this case, they were LEO at the subdistrict level and AEFSB at the district level. As the intermediary institutions, these two institutions were required to be active in capturing community aspirations and identifying its problems, and also needed to be active in finding solutions and technological innovation needed by society.

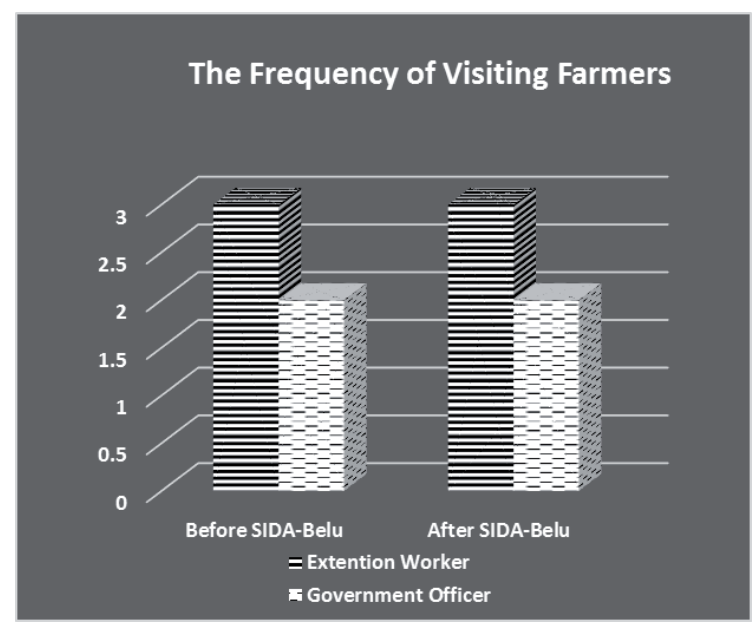

Figure 4. The Frequency of Extension Workers Visiting Farmers

For these reasons, the intermediary institutions should actively coordinate with relevant agencies.

The local intermediary institution (LEO) that was assigned to manage SIDa-Belu consisted of extension workers that had a duty to assist farmers, which was conducted usually by training and visiting farmers' groups.

Although there was no significant difference in the frequency of extension workers' visits to farmers before and after the SIDa-Belu implementation as shown in Figure 4 (1-3 times in a month for extension worker, and 1-3 times a year for government officers at a district level), after the implementation, the information was disseminated evenly. This was indicated by the knowledge of all farmers involved on SIDa-Belu, and not only the head of farmers' groups or prominent members of farmers' groups. In addition, the information both from central, province or district-level government was better managed by LEO to be disseminated evenly to farmers.

At the subdistrict and village levels, the SIDa-Belu functioned according to the needs of the farmers. However, to make SIDa-Belu more effective in the district level, there were still some problems to be solved. These were the lack of coordination among offices at the district level, including the agricultural and plantation office, the fishery office, the animal husbandry office, the forestry office, the communication and informa- 
tion office, and the Agency Extension and Food Security Board (AEFSB).

In order to make the innovation systems function as desired, interaction across all the parties were compulsory. Coordination was one way to build interaction among these parties. If there was no coordination, then all information or programs would not perform effectively or not be well-distributed, and as a result, the people/ farmers would not benefit from the program.

The other problem was that knowledge and information was not well-transferred from one officer to the other. For example, when someone involved in SIDa-Belu development and implementation was shifted or promoted to another position or area, the knowledge and information went with this person, and the one replacing the position would have no knowledge and information about the SIDa-Belu program and hence it would all have to start from the beginning. With this condition, the progress of SIDa-Belu in its objective to help poverty alleviation was disturbed. Therefore, institutional transformation required changes in the attitude, behavior and mindset of innovation systems actors.

Hounkonnou et al., (2012) write that "changing institutions requires brokers who strategically facilitate the formation of, and interaction in, temporary configurations of key actors carefully selected as champions for some social purpose". The federal and state institutions had their mandate in public policy. These institutions increasingly interacted, resulting in a situation where the line between public and private became increasingly vague (Hounkonnou et al., 2012). Though there were no significant differences in the frequency of visits to farmers before and after SIDa-Belu implementation, the knowledge and information gained by the farmers after the implementation indicated that the extension worker was able to transfer and disseminate innovation to the farmers.

This change can be seen from the change in cropping pattern applied by the farmers (Figure 5). All information and innovation to be disseminated in a community should be managed by the LEO, where the technology can be easily disseminated to those in need. Through this mechanism, the
LEO would also be able to arrange or propose programs and identify information needed by farmers with more ease.

In functioning the SIDa-Belu Model, the active involvement of the farmer's community was very important. The SIDa-Belu was built based on the needs of the users, i.e. farmers. In the process of building SIDa-Belu Model, the ones who used and how the habits of the user were factors that were taken into account for the model. Innovators and innovation disseminators also have to get to know and understand the needs of farmers, and also have responsibility to widely distribute the innovation. In addition, infrastructure facilities and local government policies were an important support in the implementation process of SIDaBelu Model.

Institutional change is a major factor in the institutional transformation. Institutional change can occur gradually or rapidly as people develop alternative behavioral patterns in response to the process and perceived benefits (North, 1990). Referring to North (1990), institutional change can be seen in the following five characteristics: (i) institutional and organizational interactions that occur continually and reinforced by competition is the key for institutional change; (ii) competition will push the organization to invest skills and knowledge to survive; (iii) the institutional framework to provide incentives dictate the kind of skills and knowledge that are considered to have a maximum exchange; (iv) perception comes from mental construction of the actors; and (v) economic coverage is complementary, and institutional network externalities create institutional changes.

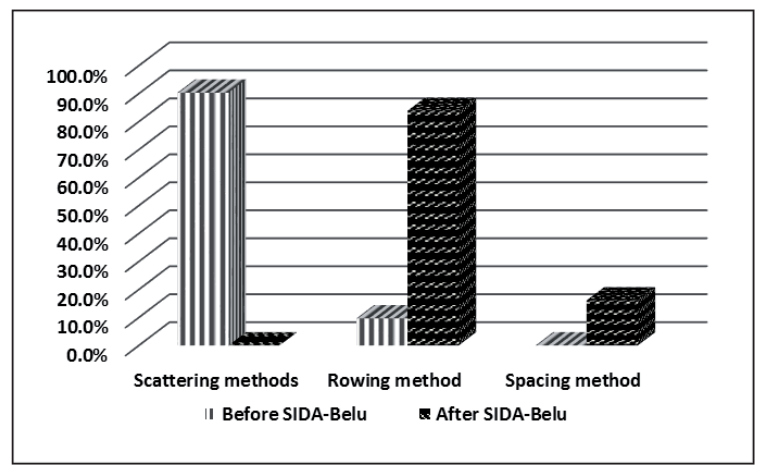

Figure 5. Cropping Pattern Before and After SIDa-Belu 
In the case of the implementation of SIDaBelu in West Tasifeto subdistrict, application only happened after the actors in the model interacted through discussions that resulted in agreements. Prior to SIDa-Belu implementation, poor farmers in West Tasifeto subdistrict had little access to knowledge and technology, while they began to believe that opportunities opened with the application of the SIDa-Belu Model.

After several socialization activities, the farmers were made aware of their disadvantages and thus grasped the opportunity to participate in the SIDa-Belu Model offered in their areas. The technological innovations were incentives for the farmers to increase their production. The SIDaBelu Model required a change from a passive to an active mindset in terms of seeking information that could help farmers' groups in finding innovation and new technologies for their benefit. These precise attitudes and similar perceptions towards SIDa-Belu Model created institutional changes in farmers' groups. Originally, in local farmers' organizations, there were minor rules with unfocused and short-term goals, but then the farmers' groups shifted into activity, now having mutually agreed rules and long-term goals.

The implementation of SIDa-Belu was based on agreement among the actors, who considered the potential benefits. With this in mind, a change was required for actors in the systems. The required changes were agreed upon among the actors and accepted to be implemented in their activity, becoming norms or values (rules) which drove the system.

However, local government officials had a different perception: the lack of competition among local offices and the absence of needs to expand the scope of economic, complementarity and network externalities resulted in passive interaction between local government offices in Belu District. It led to a stagnant functioning of the SIDa-Belu Model at the district level and among government offices in Belu. However, the condition did not affect the performance of the SIDa-Belu Model at user/village level, where farmers were actively involved in the model, supported by the LEO as the intermediary institution.
This situation motivated conflict between the LEO who manages SIDa-Belu and technical district-level offices, as well as WGDP3 as a part of the SIDa-Belu Model, creating a gap that could slow down the functioning of SIDa-Belu. Figure 6 demonstrates that offices at the district level have not yet performed their conceptual role in the innovation system. For example, it was agreed that twice a month, the Office of Communication and Information would facilitate internet for the farmers through mobile connections set up in the LEO, and until the research implementation (in 2015), this was still not achieved. From FGDs conducted in 2015, the problem of funding and internet operation had gone unfulfilled in their responsibility.

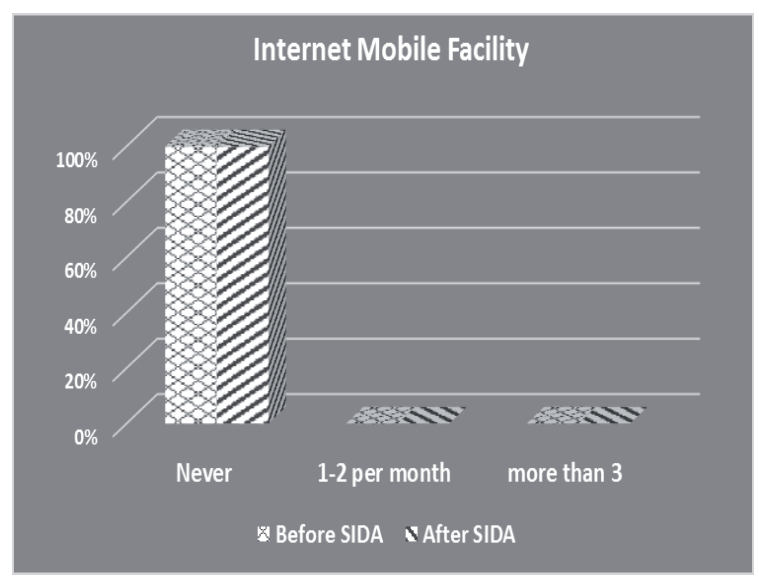

Figure 6. Number of Visit of Internet Mobile Facility

\section{SIDa-Belu Performance}

From the evaluation of the SIDa-Belu Model, some points were derived and analyzed as follows:

\section{(1) The Performance of Intermediary Institution}

Such innovation networks are dependent on many other peripheral actors in their institutional environment whose involvement may not be voluntary but, rather, predicated by mutual interdependence (Klerkx, Aarts, \& Leeuwis, 2010). For the SIDaBelu Model in West Tasifeto subdistrict, the LEO was assigned as the intermediary institution to connect the government to farmers. In general, before and after the SIDa-Belu Model was implemented in the community, farmers' perception on 
the performance of LEO was adequate. While the existing personnel was inadequate, the LEO still sent extension workers to farmers' groups although it did not cover every group in consideration of the coverage area, which is too large to entirely cover.

For farmers, the performance of LEO in managing SIDa-Belu was 'fair' to 'good'. Around $68 \%$ respondents gave a rating of 'fair', and the remaining 32\% gave 'good'. Each score can be seen in Figure 7.

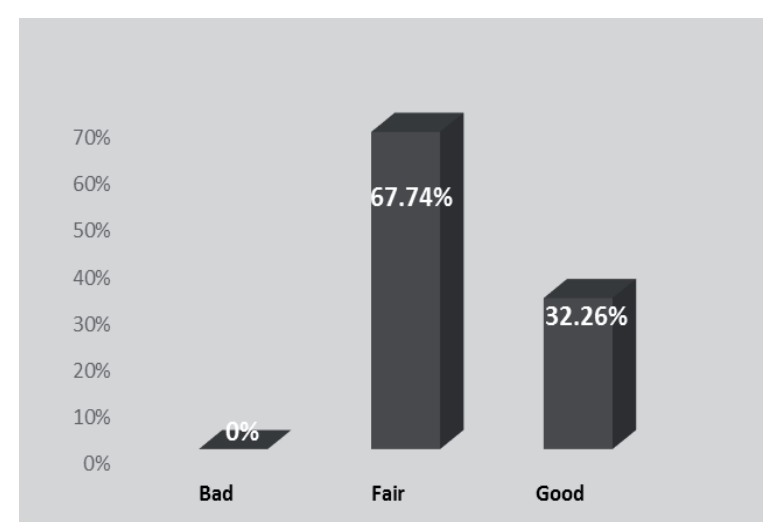

Figure 7. Performance of LEO as SIDa-Belu manager

In searching and providing information, the people/farmers still considered the performance of the LEO (BP3K) to be bad, with only $32 \%$ of respondents giving a 'good' rating, and the rest (68\%) giving a 'bad' rating. This was because the LEO only accommodated information needed for agricultural technology, but did not provide other information about non-agricultural technology, for example veterinary issue and food processing issue, that was needed by farmers, both before and after the implementation of the SIDa-Belu Model.

Besides farming, the community also raises livestock in their communal ranch. However, the experiences of extension officers were from an agriculture discipline. In any case, the extension workers did not have any scientific background in agriculture. They were recruited just for their experiences. In keeping the farmers motivated, the farmers rated the performance of LEO as 'fair' and 'good' because they communicated and gave inspiration to the farmers in developing or searching for needed technologies through networking with other farmers groups in other areas, both before and after the implementation of the SIDa-Belu Model (Figure 8).

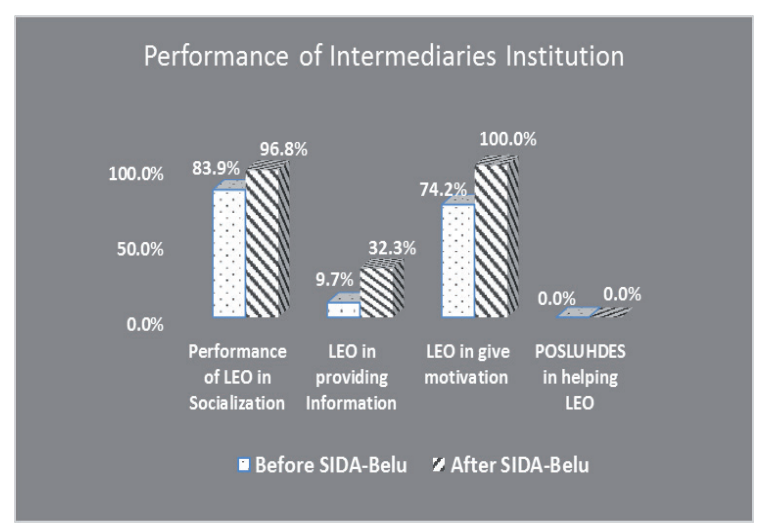

Figure 8. The Intermediary Institution Performance

As an intermediary institution, the LEO requires good knowledge and information input as extension materials. With limitations in the quality and quantity of extension workers, the performance of LEO in serving the needs of farmers was considered just adequate or fair. Currently, the LEO only has three extension workers with educational qualifications-one with a bachelor degree, and the other two with high school degrees-but they were expected to master all subjects in agriculture, animal husbandry, plantation and fisheries. With their existing capacity, the extension workers are not able to master all of these subjects; moreover, it was not able to cover the full extent of their working area. This was due to the area they had to cover being too large, with rough conditions and long distances between hamlets, so direct extension activity was hard and a burden for the extension workers.

\section{(2) The Performance of Innovation Provider (R\&D Sector)}

Many of the institutions that played crucial roles in creating smallholder opportunity had formal functions or purposes that had very little to do with the actual function (Roling et al., 2012). The R\&D centers had a crucial role in developing innovation for farmers and the underdeveloped community. However, sometimes they have difficulties in transferring their knowledge to the community. 
East Nusa Tenggara is considered an underdeveloped region in Indonesia, one of the reasons is lack of information and innovation. During the SIDa-Belu Model implementation in West Tasifeto subdistrict, there were several simple agricultural innovations that had been disseminated by the R\&D centers. One of the innovations was fruit farming technology, specifically pineapple cultivation, organic fertilizing and vegetable cultivation. As originally the farmers were mainly corn farmers and corn farming technology was different with vegetable farming cultivation, vegetable farming was a new innovation for farmers in the location where SIDa-Belu was implemented. The performance of the innovation providers was measured by how many farmers adopted the innovation.

Once implemented, SIDa-Belu brought changes in the commodities grown and in the variety of commodities. Before, they only grew corn and nuts as staple food (Saparita et al., 2013). During the implementation, vegetables and pineapples were introduced as cash crops that could be sold to generate income in a short period of time (Saparita et al., 2013). After the implementation, $36 \%$ of farmers grew one or two varieties of vegetables, while $6 \%$ still cultivate the same varieties. The remaining $58 \%$ of farmers changed the commodity grown and added more varieties (Figure 9).

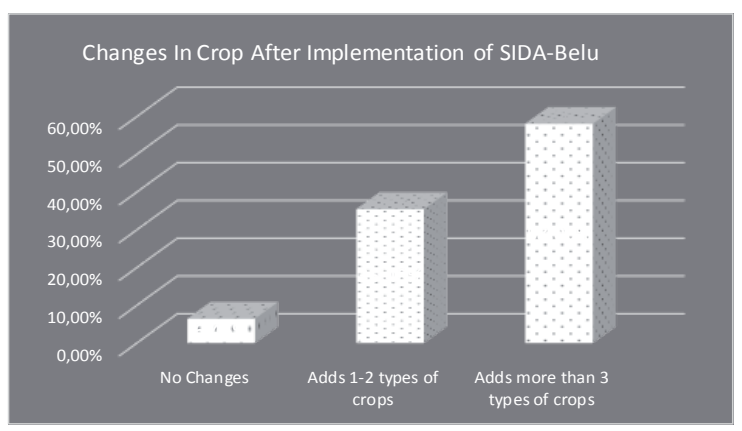

Figure 9. Changes in Crop after Implementation of SIDa-Belu

During the implementation of the SIDa-Belu Model, other farmers' groups in other areas were interested in participating in the system. This par- ticular farmers' group was made up of vegetable cultivators. Before SIDa-Belu was implemented, almost all the farmers (90\%) planted vegetables by scattering the seeds. After the implementation, $86 \%$ of the farmers grew their vegetables in a row pattern, and $14 \%$ percent of them, besides applying row patterns, also considered spacing. With these changes, on average they managed to earn Rp670,000 per harvest (equal to US \$52). Previously, they earned Rp520,000 per harvest (equal to US \$40), showing an increase of around $29 \%$. This meant that the innovation was successful in creating a larger benefit for farmers.

In this case, a change in cropping pattern indicated that the innovations were adopted by farmers. Farmers adopted the technology introduced because they trusted the R\&D and extension workers who introduced the innovations and they were confident that the technology introduced gave them benefits. This trust then led to changes in farmers' groups' institutions, such as adopting the new cropping patterns. The trust also encouraged them to actively participate in the SIDa-Belu Model. The transformation from individual farmers into farmer's groups occurred due to the farmers' interests and needs in the system. Their interests concerned the facilitation for the needs of agricultural inputs (seeds and fertilizers), information and technology and the marketing of their agricultural products.

\section{(3) Performance on Institution Changes of Farmers'groups (Community Sector)}

In the institution, there were formal and informal rules which influenced the transformation of the institution. The informal constraints that are culturally derived would not change immediately in reaction to the changes in the formal rules, leading to a tension between altered formal rules and the persisting informal constraint. Chavance (2008) stated that changes in formal rules are made and enforced by some policies, while informal constraints are linked to cultural inheritance.

In putting the SIDa-Belu Model into action, there was an agreement on hatusan, informal rules that were included in formal rules. Hatusan is a custom governing relationship between farmers, groups, disseminators and innovators. When the 


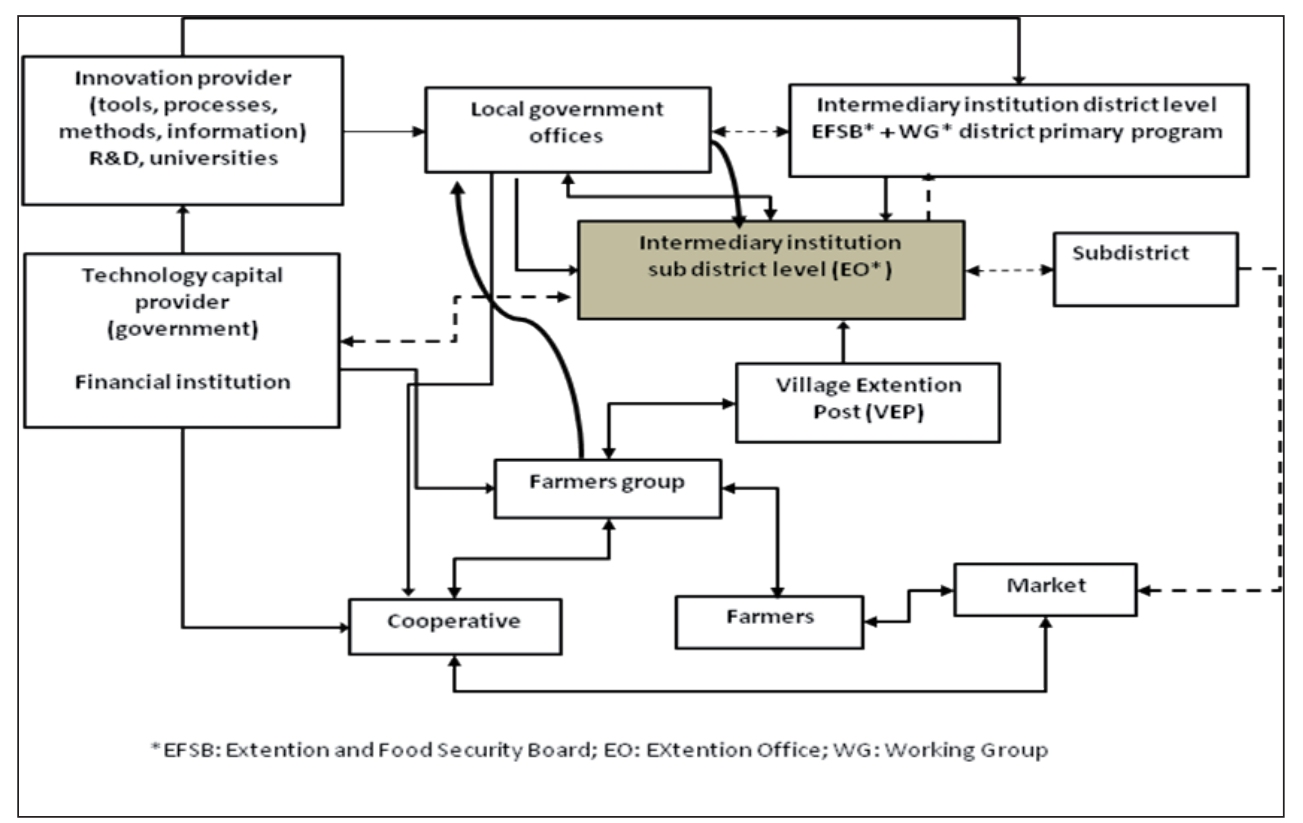

Figure 10. The Modified Networking Structure of Innovation System

rules were violated, there would be punishment and the penalties were determined by custom. In implementing the SIDa-Belu Model, hatusan here was used as a reward and punishment mechanism agreed by the community. However, in practice, it has not yet been applied. The reason for its lack of application was because the punishment was considered too harsh on the farmer. This punishment decreed that any violations of the agreement would lead to exclusion from the government's programs for one year. As such, they would conduct another meeting to adjust the rules which all farmers would agree upon. Moreover, each farmer's group still competed to receive government assistance through various programs.

The competition has made each farmer's group keep information to them. Other problems that arose as a result of competition among farmers' groups were that not all farmers' group fully participated in the SIDa-Belu Model. This situation arose because a group of farmers believed that the systems prevented individual initiatives, which meant that the individual could not look for government program by him/herself even if she/he had personal, advantageous relations. To some people who were socially active and had a large network, the systems would restrain their initiative and creativity. However, through dia- logue among actors in the system, it was agreed to modify the model to accommodate individual creativity and initiative as long as it benefited the people and further development of the system; it still had to be reported to the LEO so assistance can be given when needed, as shown in Figure 10. This showed that when an informal rule restrains benefit for a group, its authority would decline in the group. Modification was needed to improve the institutional performance of SIDa-Belu.

\section{CONCLUSION}

Institutional change is a permanent transformation process that is a part of development. Therefore, the main objective of institutional change is to internalize the potential for greater productivity and increase in resource utilization, simultaneously creating a new balance. In the application of the SIDa-Belu Model in West Tasifeto subdistrict, institutional changes encouraged changes in farmers - from subsistent before, to farmers ready for the market through new adjustments that are supported by external factors (with a permanent feedback process).

The implementation process of the SIDaBelu Model started with dialogue, moved to problem formulation and ended with an agreement to conduct intersectoral coordination and 
communication. Interaction among the farmers was built through series of FGDs and dialogues; personal approaches to farmers' groups were carried out to build an understanding on the role and benefit of SIDa-Belu for them. In actioning the SIDa-Belu Model, knowledge transfer on vegetables cultivation technology was conducted. Fruit and vegetable cultivation technologies were introduced to farmers as cash crops.

The institutional changes occurred as a shift from minor rules with unfocused and short-term goals, into active farmers' groups, with rules mutually agreed upon and long-term goals.

This study also illustrated that the concept of innovation systems can be used as an instrument in poverty alleviation. Although it does not directly alleviate poverty, by bridging the innovation from innovation providers to users, users can make use of the innovation optimally and increase the community's welfare.

The innovation system as described by the implementation of the SIDa-Belu Model indicated that innovation can be more focused on users' needs and can also encourage better organization for farmers, assisting farmers in increasing their economic welfare. It was agreed amongst the members that every activity should be documented and reported to the LEO, so the LEO owned a database of every activity in and condition of the area, which would be a good base for planning and proposing programs to district-level government.

For innovators, dissemination of innovation or technology would be more convenient with the help of extension workers and support from local government. The innovation would develop with a larger focus on users' needs and be disseminated effectively and evenly. The SIDa-Belu Model also encouraged good and active communication amongst farmers and farmers' groups, which also could reduce conflict and increase cooperation among farmers.

The agreed-upon rules and the controlled conducts in each actor and among actors of SIDa-Belu Model produced a well-performing local innovation system. The institutional transformation occurred as a shift from minor rules with unfocused and short-term goals, into active farmer's groups with rules mutually agreed upon and long-term goals. The successful institutional transformations are seen in the changing attitudes of the actors toward a better organization, which demonstrates the benefit received by the farmers as target of the program.

\section{ACKNOWLEDGEMENTS}

The authors extend their great gratitude to the Center for Appropriate Technology Development at the Indonesian Institute of Sciences (CATDevIIS) in Subang, West Java and Pappiptek LIPI for their contribution and cooperation in this study. Thanks is also addressed to the local government and community of Belu, East Nusa Tenggara.

\section{REFERENCES}

Arranz, N., de Arroyabe, \& Fdez, J. C. (2009). Technological cooperation: A new type of relations in the progress of national innovation systems. The Innovation Journal: The Public Sector Innovation Journal, 14(2).

Audretsch, B. D. \& Link, N. A. (2012, February). Entrepeneurship and innovation: Public policy frameworks. Journal of Technology Transfer, 37, 1-17. (http://dx.doi.org/10.1007/s10961011-9240-9)

Carayannis, E. \& Grigoroudis, E. (2014). Linking innovation, productivity, and competitiveness: Implications for policy and practice. Journal of Technology Transfer 39(2) 199-218. doi:10.1007/s10961-012-9295-2. (http://dx.doi. org/10.1007/s10961-012-9295-2)

Chavance, B. (2008). Formal and informal institutional change: The experience of psotsocialist transformation. The European Journal of Comparative Economics, 5(1), 57-71.

Dyah, S., Saparita, R., Abbas, A.,Mulyadi, D., \& Hidayat, W. E. (2011). Inovasi dan kemiskinan: Studi peran inovasi dalam menanggulangi kemiskinan. [Innovation and Poverty: The Role of Innovation in Poverty Alleviation] Jakarta: LIPI Press.

Edwards, E., Allen, J. A., \& Shaiik, S. (2006). Market structure conduct performance (SCP) hypothesis revisited using stochastic frontier efficiency analysis. Annual Meeting, the American Agricultural Economics Association. California. 
Foxon, T. \& Pearson, P. (2008). Overcoming barriers to innovation and diffusion of cleaner technologies: Some features of a sustainable innovation policy regime. Journal of Cleaner Production, 148-161. (http://dx.doi.org/10.1016/j. jclepro.2007.10.011)

Horton, D. \& Mackay, R. (2003). Using evaluation to enhance institutional learning and change: Recent experience with agricultural R\&D and development. Agricultural System, 78, 127-142.

Hounkonnou, Dominique., Kossou, Dansou., Kuyper, Thomas, W., Leeuwis, Cees; Nederlof, Suzanne., Roling, N., Dawson, O.S., Traore, M., \& Huis, V. A. (2012). An innovation systems approach to institutional change: Smallholder development in West Africa. Agricultural Systems. 108, 74-83 (http://dx.doi. org/10.1016/j.agsy.2012.01.007)

Jacobsson, S., and Johnson, A. (2001). The emergence of growth industry: A comparative analysis of the German, Dutch, and Swedish wind turbine industries. Schumpeter Conference. Manchester.

Johnson, A. (2001). Functions in innovation system approaches. Retrieved June 26, 2015 from http://www.druid.dk/uploads/tx_picturedb/ ds2001-205.pdf.

Juma, C. (2014). Complexity, innovation, and development: Schumpeter revisited. Policy and Complex System, 1(1).

Klerkx, L., Aarts, N. \& Leeuwis, C. (2010). Adaptive Management in Agricultural Innovation Systems: The Interactions between Innovation Networks and their Environment. Agricultural Systems 103(6), 390-400

Lakitan, B. (2010). Revitalisasi Kelembagaan Riset dan Pengembangan untuk Mendukung Sistem Inovasi Nasional. [Revitalization of Research and Development Institutional to support
National Innovation System]. [Master Thesis] Universitas Sahid, Jakarta.

Lundfall, B.A (ed.) . (2007). Innovation system $R \& D$ and policy where it came from and where it might go. CAS Seminar. Oslo.

Muller, E. (2009). Innovation system and policies. Retrieved June 26, 2015 from: http://www. evoreg.eu/doc/files/lete/200912. Emmanuel Muller_Innovation_systems_and_policies. pdf.

North, C. D. (1990). Institutional change: A framework of analysis in institutional change and economic performance. Cambridge University Press. Retrieved June26, 2015 from www.iei.liu.se/ nek/ 730A22/ filarkiv-2013/del-1a-andersson/ 1.516348/NorthInstchange_framework.pdf.

OECD. (1999). Managing national innovation system. Organization for Economic \& Cooperation Development.

Roling, N., Hounkonnou,D., Kossou, D., Kuyper, T.W., Nederlof, S., Dawson, O. S., Traoré, \& M., Huis, A. V. (2012). Diagnosing the scope for innovation: Linking smallholder practices and institutional context Introduction to the special issue. Wageningen Journal of Life Science, 60-63, 1-6. (http://dx.doi.org/10.1016/j. njas.2012.06.004)

Saparita, R., Dyah, S., Mulyadi, D., Hidayat, E.W. (2012). Model sistem inovasi dalam penanganan kemiskinan [Model of innovation sytem in tackling poverty]. Bandung: MQS.

Saparita, R., Dyah, S., Abbas, A., Hidajat, E.W. (2013). Kemiskinan dalam perspektif sistem inovasi [Poverty in innovation sytem perspektif]. Bandung: MQS.

Rijn, V. F., Bulte, F. E. \& Adekunle, A. (2012). Social capital and agricultural innovation in SubSaharan Africa. Agricultural System., 108(C), 112-122 doi:10.1016/j.agsy.2011.12.003

World Bank. (2006). Enhanching agricultural innovation: How to go beyond the strengthening of research systems. Washington D.C.: World Bank. 